UDC $372.8(510):[(81)+(82)+(87)]$

\author{
Vakarchuk K. V. \\ Ph.D., Associate Professor, \\ Department of International Relations \\ Odessa I. I. Mechnikov National University \\ r. 32, French Blvd., 24/26, Odessa, Ukraine \\ Tel.: +30482633259 \\ E-mail: katiavak30@gmail.com; m_katia@ukr.net \\ ORCID iD: https://orcid.org/0000-0001-7352-5316 \\ DOI: http://dx.doi.org/10.18524/2304-1439.2019.32.175562

\section{CHINA'S STRATEGIC PARTNERSHIP WITH LATIN AMERICA COUNTRIES: BRAZIL, ARGENTINA, AND VENEZUELA}

\begin{abstract}
The article analyzes China's relationships with strategic partners in the Latin America region: Brazil, Argentina, and Venezuela. It describes the main spheres of cooperation. The basic principles in interstate relations are pragmatic approach despite political and ideological preferences. Brazil remains the biggest trade partner in the region, which makes current Brazilian president Bolsonaru anxious. Thanks to Chinese investments, Argentina realizes the biggest energy projects. The China-Venezuela relationship is built on somewhat different principles because apart from the Venezuelan oil exports to China, the latter allots significant credits in support of Venezuelan economy and personally Maduro.
\end{abstract}

Key words: China and Latin America, strategic partnership, bilateral relations, cooperation.

Introduction. After China's accession to the WTO, its policies towards Latin America have changed dramatically, gaining the character of economic expansionism in their own interests. Such key players as Brazil, Argentina, Mexico, Venezuela, and Cuba are China's strategic partners in the region. The activity of China in the area is related to the fact that the role of Latin American countries in the international arena has grown since the beginning of the XXI century. The countries have become more independent in shaping foreign policy and taking an active part in world politics. The center-left regimes came to power in many states of Latin America in the early 2000s. It led to the deterioration of relations with the United States and the formation of closer ties with China.

With the adoption of the «One Belt, One Road» strategy in China in 2013, Latin America has taken a leading position in China's foreign policy priorities. This has led to enormous investments in the region from the PRC. It is also commonly believed that the deepening of relations between China and the countries of Latin America also had an ideological basis.

The analysis of the latest research. Over the past two decades, scholarly interest in Latin America has grown significantly in post-Soviet countries, particularly in Ukraine. There appeared new research centers on Ibero-Amer- 
ican studies, but the Institute of Latin America under the Russian Academy of Sciences remains among the most authoritative. The Center of Iberian Studies and the Association of Spanish Studies operate in Ukraine. Thus, this article bases on works by such authors as Yakovlev P. P. [9], Sudarev V. P. [6; 8], Lavut A. A. [5]. Among the representatives of the Western school, one should highlight the work of Sulivan M. [14], a researcher from the Shanghai Center for International Studies Khaibin N. [12]. The work of Chinese scientists, known as the Yellow Book "Annual Report on Latin America and the Caribbean (2012-2013)," published by the Latin American Studies Institute at the Chinese Academy of Social Sciences (CASS) made a considerable input and promoted comprehensive cooperation for future Chinese-Latin American relations [13].

The purpose of this work is the analysis of the study of intercontinental relations between China and key Latin American countries.

The primary method of research is case-study, which allowed to pinpoint individual countries: in particular Brazil, Argentina, and Venezuela in their relations with China. It was this specific method that allowed to disclose precise areas of cooperation and focus on key issues in the relationships between the states considered in the article. The methods of analysis and synthesis became auxiliary. The analytical method reveals the internal tendencies of the processes studied in the work. It also includes the results of abstraction, simplification, and formalization.

China-Latin America relations began to form on an ideological basis driven by pragmatic goals. Therefore, pragmatism can be used as a method of inquiry in this article, because it means an ideological setting for the realization of political successes, and a positive result in actions.

China's policy on Latin American countries was presented in the strategy "China's Policy in Latin America and the Caribbean» in 2008. The Chinese strategy coincided with the time when the world financial crisis began. In particular, it noted that the development of opportunities depends on many factors. The most important factors are mutual complementarity and trade and economic cooperation between China and Latin America [3].

This strategy clearly sets out the priorities, principles, and areas of cooperation. A pragmatic approach remains the basic principle of Chinese diplomacy, regardless of the ideological and political orientation of partners. Economic issues prevail over political in relations with Latin American countries [9].

Argentinean researcher Enrique Dussel notes that the problem that Latin America is currently facing is the creation of a joint Latin American program for the establishment and maintenance of strategic relations with China. There is the so-called heterogeneity in Chinese-Latin American relations since there are different degrees of proximity between the two groups of countries: those that have mutually complementary relations with China (such as Brazil, Chile, Peru, and Costa Rica) and those that have a competitive relationship with China (for example, Mexico and Argentina). He introduces the concept of heterogeneity in such relationships and indicates both the positive and the negative effects of such cooperation [13]. 
The history of China's relations with Latin American countries is rather long and rich. Since 1990, China began a dialogue with the Rio Group and then joined the Treaty on the Prohibition of Nuclear Weapons in Latin America and the Caribbean. The Peoples Republic of China received observer status at the United Nations Economic Commission for Latin America and the Caribbean (ECLAC). China has established official relations with regional and subregional organizations such as MERCOSUR, CARICOM, and the Andean Community of Nations [9].

In July 2014, a meeting between the leaders of the People's Republic of China and the heads of state and government of 11 countries of Latin America took place in Brazil. The participants announced the creation of the China CELAC forum, which is a commonwealth of Latin American and Caribbean countries (includes 33 countries). The proposed format was « $1+3+6$ », where the figure «1» meant «Plan of cooperation of China with the Latin American and Caribbean states for 2015-2019». The figure «3» meant three locomotives of economic growth: trade, investment, and cooperation in the monetary and financial sector; and «6» implied priority areas for cooperation: energy resources, infrastructure, agriculture, manufacturing, scientific and technological innovations, and information technologies [5, p. 64-65].

Consequently, China maintains strategic relations with seven states of the region. China's foreign policy distinguishes between two types of strategic partnership. The first type is partners at the level of associations, unions, and forums, and the second type is of an all-embracing nature that has been established with Brazil, Argentina, and Venezuela.

The best way to observe China's relations with Latin American countries is to trace its relations with Brazil, Argentina and Venezuela. The advent of leftist regimes in the early 2000s in these countries opened a possibility for rapprochement between the countries first ideologically and then economically. The creation of BRICS united Brazil with China on a common position on international policy and participation in global processes. China and Argentina showed strong economic cooperation during Kirchner's tenure. As for Venezuela, military-technical cooperation, energy cooperation, and huge Chinese loans to support the country as a whole during its protracted crisis link the two states.

In addition to political and economic cooperation with the region, it is widely believed that it is through Latin America and the Caribbean that China is trying to change the situation regarding the support of Taiwan, because most Latin American countries recognize it. China offered the most favorable conditions to provide loans and tranches to these countries, unlike the IMF and US banks, which led to the inflow of Chinese funds into the region. The 2008 global crisis hit Brazilian economy, causing its shrinking. Argentina is still dependent on IMF tranches after the 2011 default, not to mention the ongoing lending in exchange for Venezuelan oil.

China's relationship with Brazil. Contacts between Brazil and China were established in 1812. Brazil recognized the Chinese republic in 1913 and opened its embassy there. However, until 1949, relations between the two countries 
were limited only to diplomatic contacts. During the 1964 military coup, a Chinese trade mission was deployed in Brazil. All its participants were arrested, and diplomatic relations with China were restored only in 1974 . By the beginning of the 21st century, both countries were dealing with domestic problems regarding foreign policy priorities. China was looking for new directions, and Brazil was still in the orbit of the US influence.

The strategic partnership between the two countries was signed in 1993, a significant breakthrough in the development of Sino-Brazilian relations. Both China and Brazil have long regarded themselves as natural major world centers of power, due to their geographical size, natural resources, and the special origin of countries that worked to achieve the status of great powers [12].

The relations between the two countries focused on the economic direction. They also evolved towards technological and scientific cooperation, but in the last decade, the partnership took on a global dimension with a growing emphasis on cooperation through new alliances or coalitions. In 1998-99, Brazil experienced financial instability and development after the global economic crisis. This led to the criticism of then-Brazilian president Fernando Henrique Cardozo and the process of "asymmetric globalization» that he initiated. The process contributed to the increased emphasis on trade, diversification, and economic cooperation in general with other major countries [15].

BRICS is a bright example of the intensification of cooperation between Brazil and China. It began during the presidency of L. I. Lulea da Silva from 2003 to 2011 . He was a representative of the left ideology. At that time, there was a significant increase in mutual trust between the two countries in the framework of political dialogue, and they took a common position in resolving global issues. All this resulted in the creation of the BRICS group. 2006 is considered to be the beginning of regular political consultations in the format of foreign ministers' meetings of the association member states: Brazil, Russia, India, China, and South Africa (joined in 2011).

In 2008-2009, President Lula da Silva of Brazil and the leader of the People's Republic of China Hu Jintao met nine times during bilateral meetings and at various international summits. China has become Brazil's strong support in the international arena in advancing the interest of the latter in permanent membership in the UN Security Council and its more active participation in international projects.

Economic and scientific-technical cooperation between the two countries is developing at the expense of CBERS joint program, which studies the Earth's resources with the help of the Sino-Brazilian satellite. The scientific and technical ties cover information technology, biotechnology, and nanotechnology.

In 2010, D. Rousseff became the new president of the Brazilian state. She became the follower of Lula da Silva's ideas while showing certain independence concerning foreign policy issues. Multipolarity policy formed the basis of the new administration. D. Rousseff started searching for new partners in the Asia-Pacific region, and China occupied the first place. In 2011, the Brazilian president visited China. The purpose of the visit was to deepen ties between the two countries. 
In fact, Brazil was the first Latin American country to have established a comprehensive strategic partnership with China in 2012. Both countries became South-South cooperation partners. Relations between China and Brazil were based on the "win-win" concept. The logic of such a concept was based on the balance of trade and economic exchanges. An action plan for the next five years, which envisaged deepening of cooperation in the field of trade and energy, was approved [1, p. 145].

Since 2014, there has been an intensive increase in the volume of Chinese investment in Brazil (to 250 billion dollars). In May 2015, Prime Minister of China Li Keqiang's first visit to Brazil, Colombia, Peru, and Chile took place. The purpose of the visit was to form the permanent presence of Chinese diplomatic missions and statesmen in the region. Brazil became the largest recipient of Chinese investment (about $24 \%$ in the structure of direct foreign investment in the continent), thereby sidestepping the US [6, p. 120].

The peculiarity of the Sino-Brazilian relations is the close cooperation between the two countries in a multilateral format. For example, the states have more opportunities to participate in shaping the international agenda and create new mechanisms for global participation in world processes within the framework of G20, G-5, and BRICS.

After the impeachment of D. Rousseff, M. Tomer became Brazilian provisional president. During his tenure, Brazil had status quo relations with China as he continued the policies of his predecessors. However, it was already clear that the situation would change. In 2018, the right-wing candidate J. Bolsonaru won Brazilian presidential election. His campaign was built on anti-Chinese rhetoric. He noted that it was necessary to change the situation in relations with China. Brazil, according to him, was already overly saturated with Chinese goods, and there must be a balance between Chinese and American presence in both domestic and foreign policy.

In 2018, Brazil's exports to China reached about $\$ 47$ billion, which is about twice as much as the PRC receives from the United States. In recent years, Chinese investments in Brazil have risen to $\$ 20$ billion. In such circumstances, Brazil's relations with China will continue to remain asymmetric and be guided by unforeseen circumstances rather than a strategy [7].

The new Brazilian president said that China's influence on the Brazilian energy sector reduced at the beginning of 2019. As for the interaction within the framework of BRICS, Bolsonaru has repeatedly expressed a thought on the possibility of leaving this association.

Relations between China and Argentina. Diplomatic relations between the PRC and Argentina were established in 1972. The development of bilateral relations was based on the concept of "win-win" and economic complementarity. A significant breakthrough in the search for new strategic partners in Argentina began with the rapprochement with China during K. Kirchner's tenure, from 2007 to 2015. It was a period of relations of confrontation with the United States and the rapprochement with China. Same as Brazil, Argentina reached the greatest development in relations with China in 2014 after the establishment of strategic partnership. They signed about twenty hydropower 
projects and adopted a program for expanding commodity exchange. China became Argentina's second-biggest trade partner after the US [4, p. 24-25].

The greatest deepening in relations between the two countries happened after Nestor Kirchner's trip to China and Hu Jintao's to Argentina in 2004. China, in accordance with its own strategy, created favorable conditions for coexistence using the region's raw materials. In particular, the PRC has provided financial loans to local governments, which those had to pay back with natural resources.

In 2015, the president of Argentina paid an official visit to China. They reached a number of agreements to expand cooperation between the two countries. The largest agreements were on the construction of two largest hydroelectric power stations in Santa Cruz and modernization of the railway network.

At the end of 2015, the Argentinean presidential election took place, and M. Macri, a representative of the right ideology, came to power. The state departed from a long-term rule with the implementation of the social model, which virtually ended with a default for Argentina. However, the new president did not rush to break ties and contracts with China and visited it to participate in the «One Belt, One Road» summit in 2017. Several economic agreements that included Chinese investments in the country were signed at the summit. In February 2017, Argentina's ambassador to the PRC Diego Ramiro Gelar said that intergovernmental relations are undergoing an important period in his interview for Xinhua News Agency on the occasion of the 45th anniversary of the establishment of diplomatic relations between China and Argentina.

Argentinean President Mauricio Macri attended the Belt and Road International Cooperation Summit in May 2017. The heads of the states agreed to expand bilateral mutually beneficial cooperation in various fields and establish a comprehensive strategic partnership between China and Argentina. China is Argentina's third-largest trading partner in the world, while Argentina is China's fifth-largest trading partner in Latin America [11].

In 2018, a meeting between the president of the Chinese National Nuclear Corporation and the president of the atomic power generating company in Argentina took place. They discussed the construction of two power units in Argentina at the expense of Chinese investments.

A meeting including Chinese President $\mathrm{Xi}$ Jinping and Argentine President Mauricio Macri took place in the same year. The parties agreed to open a new era of comprehensive strategic partnership between the two countries. The Chinese side is ready to take an active part in the Argentine projects, development of infrastructure, and to strengthen bilateral cooperation in the fields of energy, finance, culture, and education.

China has a long history of relations with Venezuela since Hugo Chavez came to power in 1998. With the advent of the new leader, the nationalization of the oil industry, the construction of the "New Socialism of the XXI Century", and the rapprochement with China began. During the 15 years of Hugo Chavez's rule, Venezuela became the third most important trading 
partner of China in Latin America. The basis for cooperation was the energy sector. They created joint ventures for the extraction and processing of heavy Venezuelan oil. An intergovernmental commission, which allocated loans to Venezuela through the Chinese Development Bank, has been operating at the highest level since 2001.

A joint investment fund for the development of economic cooperation between the two countries was established in 2007. To date, China has provided Venezuela with about $\$ 70$ billion in exchange for oil supplies. The Chinese government is building an oil refinery in Guangdong Province. China also participates in the megaproject on the construction of a channel in Nicaragua that will connect two oceans. It is in the interests of Caracas because the construction of such a channel leads to intercontinental supplies. However, with the political crisis in Venezuela, the project is temporarily suspended [4, p. 58].

With N. Maduro coming to power, the intensification of relations between China and Venezuela acquired the nature of regular meetings between the leaders and delegations of both countries. New contracts on the creation of new special economic zones were signed. At the same time, the greatest development of cooperation is in the military-technical sphere. Venezuela became the first customer of the VN-1 armored personnel carriers from China, and it also received $18 \mathrm{~K}-8 \mathrm{~W}$ military-training aircraft. A significant number of Venezuelan officer corps is trained in China [7].

Before the 2019 crisis, Maduro went on a 4-day visit to China in September 2018. During the visit, Venezuela and China signed 28 agreements on cooperation in education, culture, energy, oil, and mining. The signed arrangements also touched upon new developments in oil fields, gold mining, and telecommunications. The signing of new agreements took place in Beijing during the closure of the XVI Joint China-Venezuela Commission. Maduro met with the head of the State Council of the People's Republic of China, Li Keqiang, who promised Venezuela economic support and the support for the «Economic Recovery Plan» for Venezuela. China's \$5 billion loan to Venezuela could be considered a significant breakthrough. In principle, this was the main purpose of Maduro's trip.

Regarding the latest developments in Venezuela, China is showing support for the current president Maduro. However, in case Guayda comes to power through the popular presidential election, China promises further support to the Venezuelan economy and further cooperation between the two states.

Conclusion. China's activity in the Latin American region has led to the reinforcement of its positions and interests not only economically. China has made significant progress in various areas of cooperation. Since 1993, when China established a strategic partnership with Brazil, it has been working on developing global partnerships with Latin American countries. These types of the partnership were established with Brazil, Mexico, Argentina, Venezuela, Chile, and Peru. The global and strategic nature of China's policy towards Latin America is most clearly reflected in its relations with Brazil.

For example, over a long period of time, China and Brazil demonstrated a common position on the BRICS international agenda. China has become a 
huge trading partner for Brazil, making the United States second largest in commodity exchange.

With Trump coming to power, the US policy towards Latin America has changed, and China is actively pushed out of the region. The shift in focus on cooperation with the United States already happened in Brazil, which led to the development of a containment strategy towards China in the region. However, with pro-American presidents in power in both Brazil and Argentina, the states' policies today reduce the presence of Chinese interests in the region.

\section{References}

1. Vakarchuk, K. V. «Zovnishnia polityka Brazylii v period pravlinnia D. Russeff.» Aktualni problemy polityky: zb. nauk. pr. Odesa: Feniks, 53 (2014):142-149.

2. Vakarchuk, K. V. «Zovnishnia polityka Arhentyny v postbipoliarnyi period.» Visnyk ONU im. I. I. Mechnykova. Sotsiolohiia i politychni nauky. 23 (2/31) (2018): 115-127.

3. Kaspruk, V. «Kytai - Latynska Ameryka: mizh ekspansiieiu i hlobalnoiu spivpratseiu.» Tyzhden.ua. Accessed November 30, 2010. https://tyzhden.ua/World/327.

4. Katona, V. Эnerhetyka Latynskoi Ameryky: Smohut ly vedushchye derzhavы spravytsia s posledstvyiamy kryzysa y probytsia v chyslo vыsokorazvytыkh stran? M.: Lenand.

5. Lavut, A. A. «Novyi etap razvytyia kytaisko-latynoamerykanskykh otnosheny॰» Latynskaia Ameryka. 12 (2017): 59-73.

6. Latynskaia Ameryka na perelome hlobalnыkh y rehyonalnыkh trendov. Pod red. Sudareva V. P., Symonova L. N. M.: YLA RAN, 2017.

7. Polonskyi, Y. «Kytai osvayvaet Latynskuiu Ameryku. Za эkonomykoi pryshla ochered voennoi sferы.» Voennoe obozrenye. Accessed September 7, 2018. https://topwar.ru/146246-kitajosvaivaet-latinskuju-ameriku-za-jekonomikoj-prishla-ochered-voennoj-sfery.html.

8. Sudarev, V. P. «Kytai - Latynskaia Ameryka: konets «zolotoho veka»?» Latynskaia Ameryka. 11 (2017): 12-19.

9. Iakovlev, P. «La Latynskaia Ameryka v hlobalnoi stratehyy Pekyna.»Perspektivy.info. November 2, 2010. Accessed November 11, 2018. http://www.perspektivy.info/book/latinskaja_amerika_v_globalnoj_strategii_pekina_2010-11-02.htm.

10. Burton, G. "What President Bolsonaro Means for China-Brazil Relations.» The diplomat. 11 (2018). Accessed November 9, 2018. https://thediplomat.com/2018/11/what-presidentbolsonaro-means-for-china-brazil-relations.

11. China-Argentina ties at a glance. Chinadaily. Accessed December 12, 2018. http://www.chinadaily.com.cn/a/201812/02/WS5c031269a310eff30328c42e_1.html.

12. Haibin, N. «Emerging Global Partnership: Brazil and China.» Rev. Bras. Polit. Int. 53 (2010): 183-192. Accessed November 11, 2017. http://www.scielo.br/pdf/rbpi/v53nspe/ v53nspea11.pdf,

13. Latin America, Caribbean and China: sub-regional strategic scenarios. Adrián Bonilla Soria, Edit.; Paz Milet García, Edit. 1st ed. San José, C. R.: FLACSO, 2014.

14. Mark, P. Sullivan. Argentina: Background and U. S. Relations. - Congressional Research Service. 2017. Accessed August 16, 2017. https://fas.org/sgp/crs/row/R43816.pdf

15. Steen, Fryba Christensen. Brazil-China bilateral relations: Between strategic partnership and competition from the Brazilian perspective. Accessed August 16, 2017. http://web.isanet. org/Web/Conferences/FLACSO-ISA \%20BuenosAires \% 202014/Archive/9ca90f04-e22a4809-8deb-fb51f1e70546.pdf

\section{Список використаної літератури}

1. Вакарчук К. В. Зовнішня політика Бразилії в період правління Д. Руссефф. Актуальні проблеми політики: зб. наук. пр. Одеса: Фенікс, 2014. Вип. 53. С. 142-149. 
2. Вакарчук К. В. Зовнішня політика Аргентини в постбіполярний період. Вісник ОНУ ім. I. I. Мечникова. Соціологія і політичні науки. 2018. Т. 23, вип. 2 (31). С. 115-127.

3. Каспрук B. Китай - Латинська Америка: між експансією і глобальною співпрацею. URL: https://tyzhden.ua/World/327 (дата звернення 30.11.2010).

4. Катона В. Энергетика Латинской Америки: Смогут ли ведущие державы справится с последствиями кризиса и пробиться в число высокоразвитых стран? М.: Ленанд, 2016. 160 с.

5. Лавут А. А. Новый этап развития китайско-латиноамериканских отношений. Латинская Алерика. 2017. № 12. С. 59-73.

6. Латинская Америка на переломе глобальных и региональных трендов / под ред. Сударева В. П., Симонова Л. Н. М.: ИЛА РАН, 2017. 208 с.

7. Полонский И. Китай осваивает Латинскую Америку. За экономикой пришла очередь военной сферы. Военное обозрение. URL: https://topwar.ru/146246-kitaj-osvaivaet-latinskujuameriku-za-jekonomikoj-prishla-ochered-voennoj-sfery.html (дата звернення 7.09.2018).

8. Сударев В. П. Китай - Латинская Америка: конец «золотого века»? Латинская Америка. 2017. № 11. С. 12-19.

9. Яковлев П. Латинская Америка в глобальной стратегии Пекина. URL: http://www. perspektivy.info/book/latinskaja_amerika_v_globalnoj_strategii_pekina_2010-11-02.htm (дата звернення 11.11.2018).

10. Burton G. What President Bolsonaro Means for China-Brazil Relations. URL: https://thediplomat.com/2018/11/what-president-bolsonaro-means-for-china-brazil-relations/ (дата звернення 09.11.2018).

11. China-Argentina ties at a glance. Chinadaily. URL: http://www.chinadaily.com. cn/a/201812/02/WS5c031269a310eff30328c42e_1.html, (дата звернення 12.12.2018).

12. Haibin N. Emerging Global Partnership: Brazil and China. Rev. Bras. Polit. Int. 53 (special edition). P. 183-192. URL: http://www.scielo.br/pdf/rbpi/v53nspe/v53nspea11.pdf (дата звернення 11.11.2017).

13. Latin America, Caribbean and China: sub-regional strategic scenarios. Adrián Bonilla Soria, Edit.; Paz Milet García, Edit. 1st ed. San José, C. R.: FLACSO, 2014. 300 p.

14. Mark P. Sullivan. Argentina: Background and U. S. Relations. - Congressional Research Service. 2017. 29 c. URL: https://fas.org/sgp/crs/row/R43816.pdf (дата звернення 16.08.2017).

15. Steen Fryba Christensen. Brazil-China bilateral relations: Between strategic partnership and competition from the Brazilian perspective. URL: http://web.isanet.org/Web/Conferences/ FLACSOISA \% 20BuenosAires \% 202014/Archive/9ca90f04-e22a-4809-8deb-fb51f1e70546. pdf (дата звернення 16.08.2017).

Стаття надійщла до редакиї̈ 14.07.2019 
Вакарчук К. В.

кафедра міжнародних відносин ОНУ імені I. I. Мечникова

к. 32, Французький бул., 24/26, м. Одеса, 65058, Україна

\section{СТРАТЕГІЧНЕ ПАРТНЕРСТВО КИТАЮ 3 КРАЇНАМИ ЛАТИНСЬКОЇ АМЕРИКИ: БРАЗИЛІЯ, АРГЕНТИНА, ВЕНЕСУЕЛА}

\section{Резюме}

У статті проаналізовані відносини Китаю зі стратегічними партнерами регіону Латинської Америки - Бразилією, Аргентиною і Венесуелою. Визначено напрямки співпраці, показано, що базовим у відносинах між державами залишається прагматичний підхід, незалежно від політичних та ідеологічних уподобань. Встановлено, що прихід до влади в 2000-х рр. «Лівих режимів» в більшості країн Латинської Америки посилив китайську експансію в регіоні.

У зовнішній політиці Китаю щодо країн Латинської Америки виділяються два типи стратегічного партнерства, перший тип - рівень асоціації або союзу, наприклад, форум Китай - CELAC, другий тип має всеосяжний характер, і такий тип відносин був встановлений з Бразилією, Аргентиною і Венесуелою. Після прийняття в 2013 році в Китаї стратегії «Один пояс і один шлях» Латинська Америка зайняла провідне місце у зовнішньополітичних пріоритетах Китаю, що привело до вкладення значних інвестицій в регіон з боку КНР. У формуванні відносин з країнами світу Китай застосовує тактику економічної експансії над політичною. Однак очевидно, що поглиблення відносин між Китаєм і країнами Латинської Америки має й ідеологічну основу, яскравим прикладом чого є відносини з Венесуелою.

Особливістю китайсько-бразильських відносин є тісна співпраця двох країн в таких багатосторонніх форматах, як G-20 G-5 і БРІКС. Китай, до приходу Ж . Болсонару - президента Бразилії з 2019 року, був провідником інтересів Бразилії на міжнародній арені, прихильником ї̈ участі у формуванні міжнародного порядку денного та створенні нових механізмів глобальної участі в світових процесах.

Бразилія залишається найбільшим торговельним партнером в регіоні, і збереження ï економічної незалежності є предметом занепокоєння нового президента Бразилії, який заявляє про ймовірність виходу Бразилії з БРІКС і про введення обмеження на ввезення китайських товарів до Бразилії. В Аргентині китайські інвестиції задіяні в найбільших енергетичних проектах, що демонструє міцні позиції Китаю в аргентинській економіці на найближчі роки. Відносини Китаю 3 Венесуелою є особливо міцними, окільки підтримуються не тільки економічними інтересами, а й ідейно-політичною близькістю двох країн.

Ключові слова: Китай, Латинська Америка, стратегічне партнерство, двосторонні відносини, співробітництво. 
Вакарчук К. В.

кафедра международных отношений ОНУ имени И. И. Мечникова

к. 32, Французский бул., 24/26, м. Одеса, 65058, Украина

\section{СТРАТЕГИЧЕСКОЕ ПАРТНЕРСТВО КИТАЯ СО СТРАНАМИ ЛАТИНСКОЙ АМЕРИКИ: БРАЗИЛИЯ, АРГЕНТИНА, ВЕНЕСУЭЛА}

\section{Резюме}

В статье проанализированы отношения Китая со стратегическими партнерами региона Латинской Америки - Бразилией, Аргентиной и Венесуэлой. Определены направления сотрудничества, показано, что базовым в отношениях между государствами остается прагматичный подход, независимо от политических и идеологических предпочтений. Установлено, что приход к власти в 2000-х гг. «левых режимов» в большинстве стран Латинской Америки усилил китайскую экспансию в регионе.

Во внешней политике Китая в отношении стран Латинской Америки выделяется два типа стратегического партнерства, первый тип на уровне ассоциации или союза, например, форум Китай - CELAC, второй тип имеет всеобъемлющий характер, и такой тип отношений был установлен с Бразилией, Аргентиной и Венесуэлой. После принятия в 2013 году в Китае стратегии «Один пояс и один путь» Латинская Америка заняла ведущее место во внешнеполитических приоритетах Китая, что привело к вложению значительных инвестиций в регион со стороны КНР. В формировании отношений со странами мира Китай применяет тактику экономической экспансии над политической. Однако очевидно, что углубление отношений между Китаем и странами Латинской Америки имеет и идеологическую основу, ярким примером чего служат отношения с Венесуэлой.

Особенностью китайско-бразильских отношений является тесное сотрудничество двух стран в таких многосторонних форматах, как G-20 G-5 и БРИКС. Китай, до прихода Ж. Болсонару - президента Бразилии с 2019 года, был проводником интересов Бразилии на международной арене, сторонником ее участия в формировании международной повестки дня и создании новых механизмов глобального участия в мировых процессах.

Бразилия остается крупнейшим торговым партнером в регионе, и сохранение её экономической независимости является предметом беспокойства нового президента Бразилии, который заявляет о вероятности выхода Бразилии из БРИКС и о введении ограничения ввоза китайских товаров в Бразилию. В Аргентине китайские инвестиции задействованы в крупнейших энергетических проектах, что демонстрирует прочные позиции Китая в аргентинской экономике на ближайшие годы. Отношения Китая с Венесуэлой являются особенно прочными, поддерживаются не только экономическими интересами, но и идейно-политической близостью.

Ключевые слова: Китай, Латинская Америка, стратегическое партнерство, двусторонние отношения, сотрудничество. 